\title{
Aging and Exercise Training on the Neuromuscular Functions of Human Movements
}

\author{
Junichiro Yamauchi ${ }^{1,2}$ \\ ${ }^{1}$ Graduate School of Human Health Sciences, \\ Tokyo Metropolitan University; \\ ${ }^{2}$ Future Institute for Sport Sciences, \\ Japan
}

\section{Introduction}

The mechanical characteristics of muscles that control the movement are important in determining the human locomotor system and can be modified with aging and exercise training. The function of keeping or improving lower limb muscle is important for elderly individuals because such function is associated with better functional performance such as brisk walking, stair climbing and chair standing. Because many of our daily living activities are multi-joint movements, we have investigated the aging-related changes in muscle functions of the lower limb multi-joint movements over a wide range and large number of people. In this chapter, I address the importance of muscle physiology in human movements with effects of aging and exercise training for elderly individuals.

\section{Aging on the neuromuscular system}

Aging is associated with impairment of various biological functions, such as decreases in muscle mass, strength, cellular protein synthesis, bone mineral density and hormonal secretion, or an increase in adipose tissue (Goodpaster et al. 2001; Lamberts et al 1997; Snead et al. 1993). The deterioration of skeletal muscle function is one of the primary consequences of aging. Muscular strength or power in humans is usually dependent on the growth process or aging. It is known that the peak of muscular strength is generally achieved between the ages of 20 and 30 years in both men and women, thereafter gradually decreases and begins to accelerate a decline after the ages of 60 to 65 (Hakkinen et al. 1995, 1997; Lindle et al. 1997). Aging can cause to a great decline in the function of neuromuscular system both during dynamic and isometric muscle activities (Bassey \& Short, 1990; Hakkinen et al. 1995, 1997). This impairment in muscular force production appears to be dependent on the type of muscular contractions and gender: a decline in concentric strength starts earlier in ages of both men and women than eccentric strength, which also starts to decline earlier in men than in women (Lindle et al. 1997). A decrease in muscle force with aging is also associated with a reduced number of motor units (McComas et al. 1993). Such decrease in neuromuscular function seems to be occurred in selective atrophy of muscle 
fiber type. With aging process, it is greater loss in fast twitch types than in slow twitch types. Slow-twitch muscle fibers as SO (slow-twitch oxidative) fibers have characteristics in aerobic (oxidative) metabolism, slow contraction speed, and, in return, they are designed to be fatigue resistance. On the contrary, fast-twitch muscle fibers have three times faster intrinsic speeds of contraction and faster time to peak tension, produce higher twitch and tetanic tensions, have higher peak powers and reach peak power at higher speeds of contraction than slow-twitch muscle fibers; in return, they have the smaller number of both capillaries and mitochondria so that they induce fatigue quickly and need the longer recovery time to re-synthesize contractile proteins in accordance with high intensity exercises. Therefore, the aging-related decline in explosive strength can be associated with a decrease in maximum and rapid voluntary motor unit activation as well as atrophy of fast twitch fibers (Hakkinen et al. 1995). The ability of muscle to generate force explosively is especially important to move quickly so as to prevent a fall from a stumble in elderly individuals (Earles et al. 2001). The declines in physical performance or muscle force production of lower limbs among elderly individuals are a serious issue because it can be predictive of subsequent disability, bedridden and eventually early death (Guralnik et al. 1995).

\section{Aging related muscle atrophy and changes in contractile properties}

The decline in force generating capacity and muscle mass with aging is called sarcopenia. The maximum force production is strongly related to muscle mass or cross sectional area of muscle, so that the decline in maximum force production with aging can be caused by a decrease in muscle mass (Akima et al. 2001). It has been reported that a $31 \%$ decrease in the volume of quadriceps femoris is seen in elderly as compared with young individuals (Trappe et al. 2001). Furthermore, the muscle force per cross-sectional fiber area (specific tension) in the quadriceps femoris muscle (Frontera et al. 2000) and vastus lateralis muscle (Trappe et al. 2003) in human does not change with aging, so that an aging-related decrease in muscle mass is one of the key factors for loss of strength in elderly people. On the other hands, other studies have shown the reduction of specific tension in type I and Ila fibers in human vastus lateralis muscle with aging (Frontera et al. 2000; D'Antona et al. 2003; Larsson et al. 1997), implying the impairment of neural factors. In addition, reduction of muscle function and volume with aging is associated with a higher percentage of body fat in elderly individuals, due probably to a decrease in basal metabolism. More interestingly, smaller size of thigh circumference could increase a risk of death in older age (Heitmann \& Frederksen, 2009). These suggest that aging-related decline in muscle function and mass have many important aspects of health issues in elderly individuals.

Muscle contractile velocity provides important information about not only mechanochemical characteristics of the actin-myosin interaction (Huxley and Simmons, 1971) but also the contractile properties of human movements. With aging, no changes in maximum unloaded velocity are reported by the study with single muscle fiber of the vastus lateralis in young and old people (Trappe et al. 2003), although other single fiber studies on human vastus lateralis muscle have reported an inconsistency such that either decreased or unchanged maximum unloaded velocity with aging was observed depending on the type of muscle fibers or genders (D'Antona et al. 2003; Krivickas et al. 2001; Larsson et al. 1997). The animal studies have also shown no consistent results on the changes in maximum unloaded 
velocity associated with aging, e.g., a decrease in the slow twitch, soleus (Li \& Larsson, 1996; Thompson \& Brown, 1999) and a decrease in the fast twitch, superficial vastus lateralis muscle fibers (Fitts et al. 1984), while no changes in the slow twitch, soleus muscle fibers (Brooks \& Faulkner, 1988; Fitts et al. 1984) and the fast twitch, extensor digitorum longus (Brooks \& Faulkner, 1988; Fitts et al. 1984; Li \& Larsson, 1996) and flexor digitorum longus muscle fibers (Walters et al. 1990). It seems likely that the reduction of force generation rather than shortening velocity is a major factor for the impairment of physical performance in elderly individuals.

\section{Aging on the neuromuscular functions of human movements}

Although the contractile properties of isolated muscle have been extensively studied, the influence of aging on contractile properties of muscles that control the multi-joint movements has not been extensively studied. We have developed the dynamometer with a high time-resolution servo system to obtain the isotonic, force-velocity relation of knee-hip extension movements (Yamauchi et al. 2007). By using this method, muscle functions are precisely evaluated with relatively small physical stress; i.e., without generation of large force to accelerate the inertial mass (Yamauchi \& Ishii, 2007) and without a large increase in blood pressure (Yamauchi et al. 2008). To understand aging-related differences on the maximum force, unloaded velocity and power of leg multi-joint movements, the dynamometer was used to investigate the isotonic force-velocity and force-power relations of muscles that control leg multi-joint movements, and the maximum isometric force (Fmax), unloaded velocity (Vmax) and power (Pmax) were determined from the forcevelocity relation.

We compared muscle functions of bilateral and unilateral knee-hip extension movements between healthy young (age, 19-31yrs) and healthy elderly (age, 60-82yrs) women (Yamauchi et al. 2009a). Figure 1 shows a typical example of force-velocity and force-power relations of knee-hip extension movements in young and elderly individuals. We showed that Fmax and Pmax of bilateral and unilateral knee-hip extension movements were 20-30\% lower in elderly than in young women (Figure 2). On the other hand, there was no significant change in Vmax between young and elderly women and between bilateral and unilateral movements. Bilateral deficit was larger as the generation of force was larger in both young and elderly women. Also, bilateral deficit of Fmax and Pmax were not different between young and elderly women. Next, we investigated muscle functions of two hundred eighty-five recreationally active men $(n=142)$ and women $(n=143)$ aged between 18 and 82 year old volunteers for the cross sectional study (Yamauchi et al. 2010). We showed that with increasing age, Fmax/body mass significantly declined in both men $(r=-0.400, p<0.001)$ and women $(\mathrm{r}=-0.587, \mathrm{p}<0.001)$, while $\mathrm{Vmax} /$ leg length did not change with age in both men $(r=-0.033, p>0.05)$ and women $(r=-0.040, p>0.05)$. Pmax significantly declined with age in both men $(r=-0.370, p<0.001)$ and women $(r=-0.446, p<0.001)$. Figure 3 shows that maximum force and maximum power of knee-hip extension movements progressively decrease with increasing age. Both results showed the aging-related decline in maximum force and power output, but no differences in the intrinsic shortening velocity of leg multijoint movements. This finding suggests that decreases in muscle force generating capacity and power may primarily lead to the loss of mobility and a reduced capability of 
a) Young woman (23 yrs old)
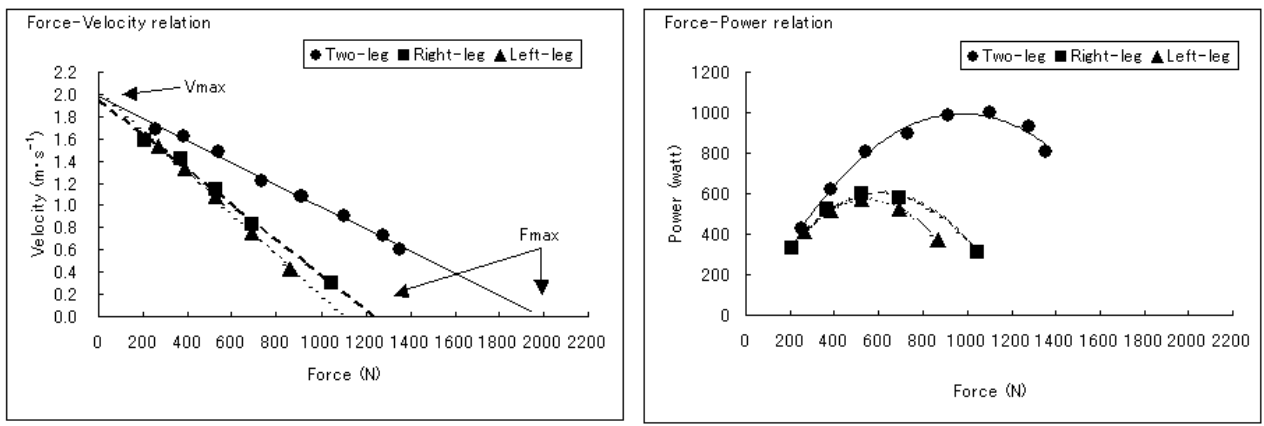

b) Elderly wom an (67 yrs old)
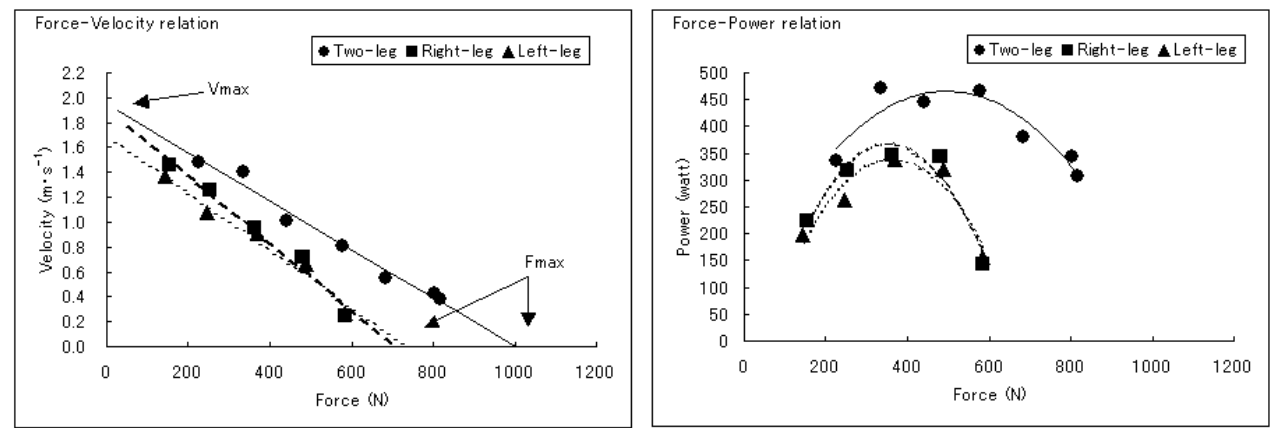

Fig. 1. Representative force-velocity and force-power relationships of bi- and unilateral knee-hip extension movements in young (a) and elderly (b) women (Yamauchi et al. 2009a) Filled circles, bi-lateral contraction (young, $\mathrm{r}=-0.99$; elderly, $\mathrm{r}=-0.99$ ); filled squares, right unilateral contraction (young, $\mathrm{r}=-0.99$; elderly, $\mathrm{r}=-0.99$ ); filled triangles, left unilateral contractions (young, $\mathrm{r}=-0.99$; elderly, $\mathrm{r}=-0.98$ ). Fmax and Vmax were estimated by extrapolations of linear regressions to zero force and velocity, respectively. Pmax was calculated as 0.5 Fmax times $0.5 \mathrm{Vmax}$.
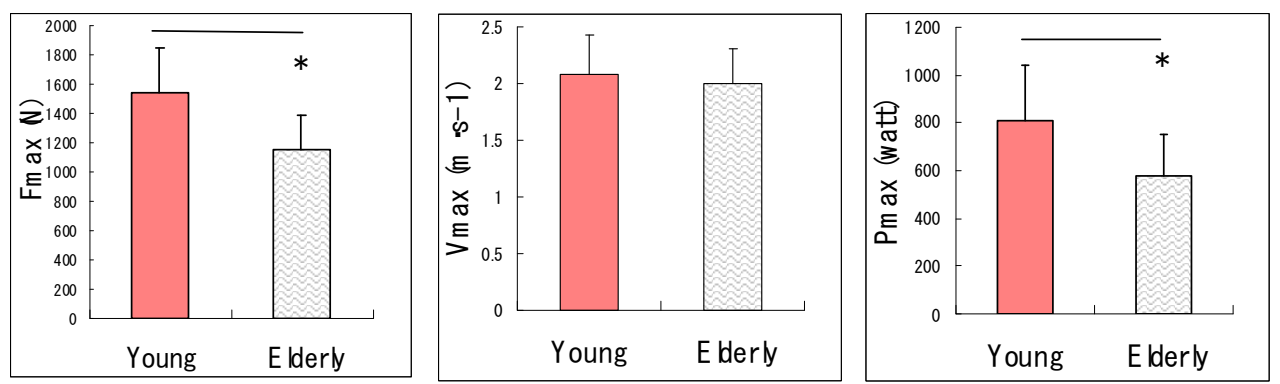

Fig. 2. Maximum isometric force (Fmax), velocity (Vmax) and power (Pmax) of knee-hip extension in young and elderly women (modified from Yamauchi et al. 2009a). Data were expressed as mean and SD. ${ }^{*} \mathrm{p}<0.01$ as compared to $\mathrm{Y}$ group. 
accelerating and decelerating the body mass during the movements. Such decrease in maximum force relative to body mass in elderly individuals indicates an increase in the risk of fall or decrease in quality of active life. This impairment of force generating capacity could be the major cause of aging-associated changes in walking ability, such as decrease in walking distance and speed (Lauretani et al. 2003). Thus, it is important to prevent a loss of force generating capacity of leg multi-joint movements in elderly individuals.
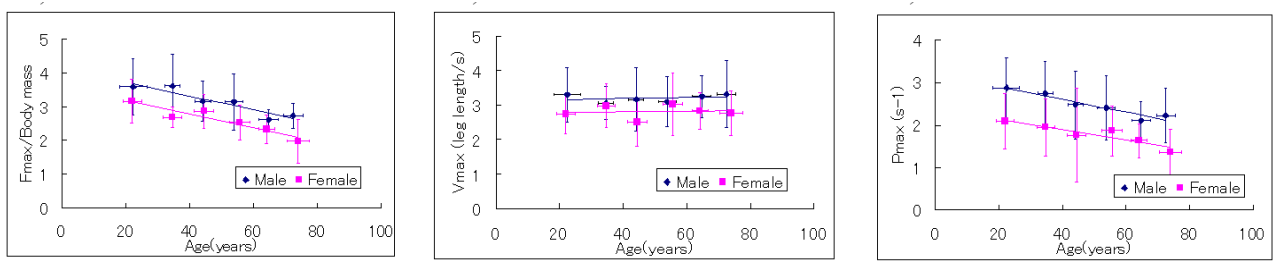

Fig. 3. Aging related changes in muscle functions of lower limb multi-joint movements (modified from Yamauchi et al. 2010)

\section{Exercise training adaptation on the neuromuscular system}

The exercise training can induce physiological adaptations in the muscle and nervous system (Bosco et al. 1986; Coyle et al. 1981; Hakkinen et al. 1989; McDonagh \& Davies, 1984). A greater force production is directly related to the muscular hypertrophy in the long-term adaptation, whereas to the neural adaptation in the short-term adaptation to the exercise training. It is well known that most of untrained individuals can easily increase the voluntary maximum force capacity without muscle hypertrophy in the early phase of strength training. The great increases in force production for untrained individuals during the early phase of training can be explained by neural adaptation in terms of an increase in both muscle activation levels and synchronous activation patterns (Hakkinen, 1989; Kreamer et al. 1996; Ploutz et al. 1994; Staron et al. 1994). As muscle fibers adapt to exercise trainings, adaptation of motoneurons occurred for satisfying a new level of physiological demands; e.g., enlargements of the cell body, nucleus, and nucleolus of the motoneuron are observed after high intensity exercises (Burke, 1975). EMG studies have shown that increases in both recruitment and firing rate as well as various facilatory and inhibitory effects in CNS are recognized during various period of strength training (Sale, 1991). As force increases, both motor unit recruitment and firing rate increase. Such training-induced neural adaptations may lead an increase in the amount of neural input to the trained muscles especially during a short period of time (Hakkinen, 1989), allowing force to develop more rapidly and peak force to be kept for a long period of time (Sale, 1988).

When strength training proceeds to the longer period, more muscular hypertrophy factors, as a result of the synthesis of new protein, will contribute to the improvement of muscle force generating capacity (McDonagh \& Davies, 1984). When the effect of muscle fiber hypertrophy increases, the motor unit activation required to produce a given force reduces. An increase in mechanical stress per unit area of activated muscle to lift a given load during exercise training can potentially be a physiological stimulus for strength gain and muscle hypertrophy, thus the strength training must be performed with progressively increases in load and with different types of movement over a exercise period (Kraemer et al. 1996; Ploutz et al. 1994). The muscle hypertrophy effects of exercise training in the human muscle 
are most prominent in the type II fibers (Komi, 1984; McDonagh \& Davies, 1984). Although the cross sectional areas of both slow-twitch and fast-twitch muscle fibers increase after the exercise training (Linossier et al. 1997; MacDougall et al. 1979; Staron et al. 1990, 1991), training-induced hypertrophy appears to be greater in fast-twitch fibers than in slow-twitch fibers. To develop the muscular size, increases in protein synthesis are required as an adaptation to increased mechanical stress (Kraemer et al. 1995; MacDougall et al. 1979; McDonagh \& Davies, 1984). An increase in muscle protein synthesis results in the construction of more myofibrils and producing greater contractile force. After the strength training, muscle fibers are recovered from damage and this process is lasted for a day or a few days depending on the intensity of exercise used and on the type of muscle involved. This recovery process generates a larger amount of protein in the muscle fiber, resulting in greater protein density, greater muscle fiber strength and size. Muscle protein synthesis may be increased by the release of growth factors and subsequent satellite cell activation as a result of muscle fiber damage (Chesley et al. 1992; White \& Esser, 1989). The time course for changes in muscle protein synthesis after strength training may be related to training variables, such as the intensity and volume of exercise; the muscle or muscle groups involved; the type of muscle contraction performed; the training state of the trainees; and training frequency and subsequent recovery from exercise.

\section{Exercise training for elderly individuals}

So, how can we prevent a decrease in muscle force and power generating capacities with aging? The maximum force production is related to muscle size and neural factors so that the decline in maximum force production with aging should be caused by a decrease in muscle size and impairment of nervous system. Aging-related loss in muscle mass and rapid voluntary motor unit activation, especially the atrophy of fast twitch muscle fibers, are key factors for loss of muscle force production in lower limb multi-joint movements for elderly people. Scientific research shows that the resistance training is an effective countermeasure against sarcopenia or aging-related loss in muscle mass and functions. Resistance training for elderly individuals has positive effects of insulin action, bone density, energy metabolism and other biological functional status, so as to improve in daily activity. Even in debilitated elderly patients, resistance training for a short period can increase isometric force and physical function (Meuleman et al 2000). Long-term exercise trainings also show the improvement of neurobehavioral functions and the reducing risks of fall in elderly individuals (Fujisawa et al. 2007). Therefore, importance of resistance training for the elderly individuals is increasing in our society.

Most of studies in exercise training are usually using strength training equipment at fitness gym or exercise science laboratory. This may lead to people thinking that it is necessary to go to the fitness gym when they want to strengthen their body. At the fitness gym, fitness trainer can teach you how to train your body more effectively and correctly with using machines. However, once you learned proper exercise with experts, you can do many exercises at home without using machines. This self-managed exercise at home is more important for elderly individuals because older individuals are simply lower in daily activity. For this reason, exercise training at home or a community center without using strength training equipment has become increasingly in demand by elderly individuals. Some home-based exercise programs have shown benefits to functional abilities in daily activities of elderly individuals (King et al. 1991; McMurdo \& Johnstone, 1995). It is 
important to understand how exercise training with using own bodyweight in elderly individuals affects muscle functions that relate to daily activity.

We have shown that exercise training using only body weight for a 10-month period successfully increased maximum force on average $15 \%$ and power output $13 \%$, but left unchanged maximum unloaded velocity of leg multi-joint movements (Figure 4). Increased muscle force and power output of the knee-hip extension movement after the exercise training is likely due to an increase in muscle mass and improved muscle activation level. Also, improvement of muscular coordination in lower limbs could give rise to an increase in maximum force and power of knee-hip extension movement. Exercise training with leg multijoint movements such as squat may largely provide increases in muscle force and power of knee-hip extension movement because specific movements favor to contribute improvement in coordination of agonist-antagonist muscle activity in multi-joint movements.

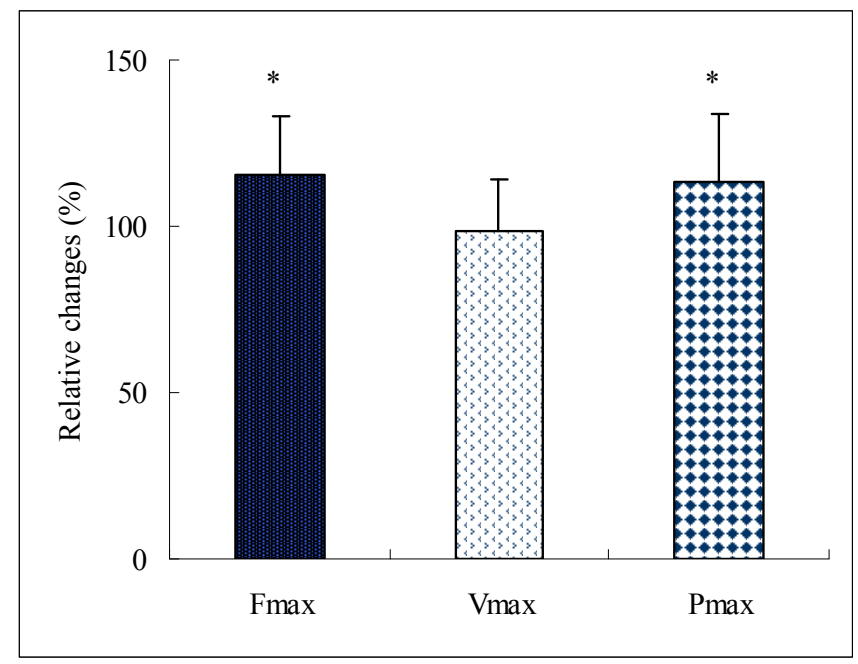

Fig. 4. Relative changes in maximum force (Fmax), velocity (Vmax) and power (Pmax) of lower limb multi-joint movements after the bodyweight based exercise training (modified from Yamauchi et al. 2009b). *Denotes a significant difference from pre-exercise training value $(\mathrm{p}<0.001)$.

Improvement of lower limb muscle force generating capacity after the exercise training could provide a positive influence on activities of daily living in elderly individuals. Increases in relative force and power reduce a risk of fall and increase quality of active life in elderly individuals (Tinetti et al. 1988). A greater muscle force generation can lead a better capability of accelerating and decelerating bodyweight during the movements and this capability will help elderly individuals to remain independent. The magnitude of increase in maximum force is related to the training intensity in elderly individuals (Figure 5). Individuals with higher exercise intensity gained greater increase in maximum force. This suggests that bodyweight-based resistance exercises could give enough training stimuli for individuals with a lower level of maximum force level, but not for individuals with an already high level. For the bodyweight based exercise training program, body weight 
relative to maximum force is an important parameter as a training intensity to determine the effects. When exercise trainings with own bodyweight continuously perform for a long term, their effects may dilute as time goes by because of increase in strength or decrease in training intensity. Thus, training intensity should change progressively with external resistance, movement speed, variation of exercise and frequency. It is generally suggested that strength training twice per week or even three times per week is optimal for improvements in strength, power and functional performance in elderly individuals. Further study needs to investigate frequency and other valuables of exercise training with using own bodyweight. Appropriate measurements of muscle function and subsequent exercise prescription in the multi-joint movements of the lower limbs are essential for the aged population.

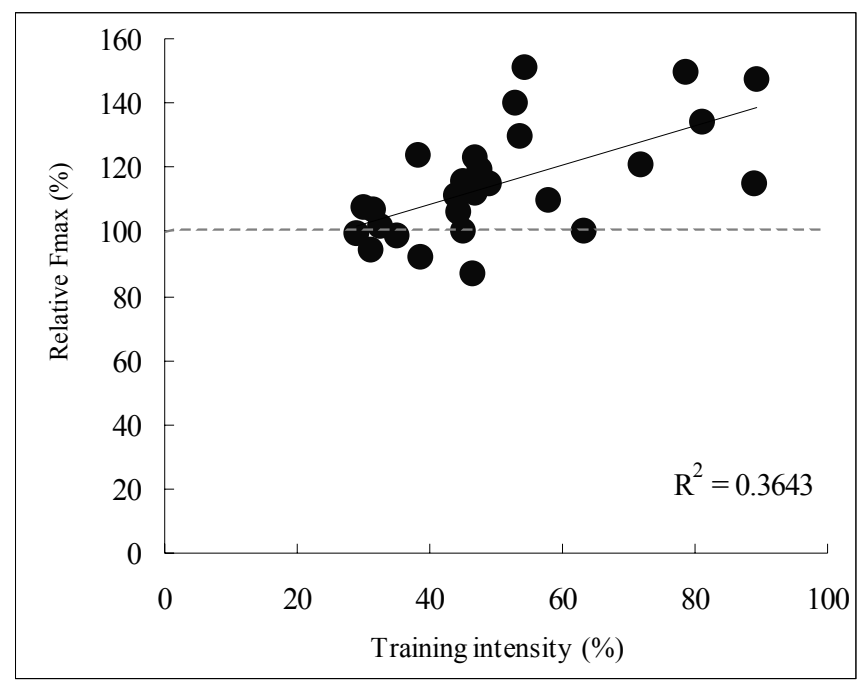

Fig. 5. Relationship between training intensity and \% changes in maximum force (Fmax) after the bodyweight based exercise training (Yamauchi et al. 2009b)

\section{Conclusion}

It is important to understand the aging-related differences in muscle function of lower limb multi-joint movements because they are profoundly related to the movements of daily living. Aging-related decline in muscular power performance of multi-joint movements in the lower limbs has much larger effects on the force generating capacity than on the shortening velocity of muscles, because, with aging process, the maximum force generating capacity declined, whereas the maximum shortening velocity was not affected. This suggests that decreases in muscle force generating capacity and power with aging may primarily cause to the loss of mobility and a reduced capability of accelerating and decelerating body mass during leg multi-joint movements in elderly individuals. On the other hands, the exercise training is considered as important countermeasure against sarcopenia. Exercise training using own bodyweight was effective to increase in muscle 
force and power of leg multi-joint movements in elderly individuals. An initial training status was important for progressive increases in muscle force of leg multi-joint movements in elderly individuals. Proper assessment of muscle functions prior to exercise training is important for elderly individuals to provide better exercise prescription at home or a community center.

\section{References}

Akima H, Kano Y, Enomoto Y, Ishizu M, Okada M, Oishi Y, Katsuta S \& Kuno S (2001). Muscle function in 164 men and women aged 20--84 yr. Med Sci Sports Exerc 33, 220-226.

Bassey EJ \& Short AH (1990). A new method for measuring power output in a single leg extension: feasibility, reliability and validity. Eur J Appl Physiol Occup Physiol 60, 385-390.

Bosco C, Rusko H \& Hirvonen J (1986). The effect of extra-load conditioning on muscle performance in athletes. Med Sci Sports Exerc 18, 415-419.

Brooks SV \& Faulkner JA (1988). Contractile properties of skeletal muscles from young, adult and aged mice. J Physiol (Lond) 404, 71-82.

Burke RE (1975). Motor unit properties and selective involvement in movement. Exerc Sport Sci Rev 3, 31-81.

Chesley A, MacDougall JD, Tarnopolsky MA, Atkinson SA \& Smith K (1992). Changes in human muscle protein synthesis after resistance exercise. J Appl Physiol 73, 13831388.

Coyle EF, Feiring DC, Rotkis TC, Cote RW, Roby FB, Lee W \& Wilmore JH (1981). Specificity of power improvements through slow and fast isokinetic training. J Appl Physiol 51, 1437-1442.

D'Antona G, Pellegrino MA, Adami R, Rossi R, Carlizzi CN, Canepari M, Saltin B \& Bottinelli $R$ (2003). The effect of ageing and immobilization on structure and function of human skeletal muscle fibres. J Physiol (Lond) 552, 499-511.

Earles DR, Judge JO \& Gunnarsson OT (2001). Velocity training induces power-specific adaptations in highly functioning older adults. Arch Phys Med Rehabil 82, 872-878.

Fitts RH, Troup JP, Witzmann FA \& Holloszy JO (1984). The effect of ageing and exercise on skeletal muscle function. Mech Ageing Dev 27, 161-172.

Frontera WR, Suh D, Krivickas LS, Hughes VA, Goldstein R \& Roubenoff R (2000). Skeletal muscle fiber quality in older men and women. Am J Physiol, Cell Physiol 279, C611-C618.

Fujisawa M, Ishine M, Okumiya K, Nishinaga M, Doi Y, Ozawa T \& Matsubayashi K (2007). Effects of long-term exercise class on prevention of falls in community-dwelling elderly: Kahoku longitudinal aging study. Geriatr Gerontol Int 7: 357-362.

Goodpaster BH, Carlson CL, Visser M, Kelley DE, Scherzinger A, Harris TB, Stamm E \& Newman AB (2001). Attenuation of skeletal muscle and strength in the elderly: The Health ABC Study. J Appl Physiol 90, 2157-2165.

Guralnik JM, Ferrucci L, Simonsick EM, Salive ME \& Wallace RB (1995). Lower-extremity function in persons over the age of 70 years as a predictor of subsequent disability. N Engl J Med 332, 556-561. 
Häkkinen K (1989). Neuromuscular and hormonal adaptations during strength and power training. A review. J Sports Med Phys Fitness 29, 9-26.

Häkkinen K, Kraemer WJ \& Newton RU (1997). Muscle activation and force production during bilateral and unilateral concentric and isometric contractions of the knee extensors in men and women at different ages. Electromyogr Clin Neurophysiol 37, 131-142.

Häkkinen K, Pastinen UM, Karsikas R \& Linnamo V (1995). Neuromuscular performance in voluntary bilateral and unilateral contraction and during electrical stimulation in men at different ages. Eur J Appl Physiol Occup Physiol 70, 518-527.

Häkkinen K, Mero A \& Kauhanen H (1989). Specificity of endurance, sprint and strength training on physical performance capacity in young athletes. J Sports Med Phys Fitness 29, 27-35.

Heitmann \& Frederksen (2009). Thigh circumference and risk of heart disease and premature death: prospective cohort study. BMJ. 339:b3292.

Huxley \& Simmons (1971). Proposed mechanism of force generation in striated muscle. Nature 233, 533-538.

King AC, Haskell WL, Taylor CB, Kraemer HC \& DeBusk RF (1991). Group- vs home-based exercise training in healthy older men and women. A community-based clinical trial. JAMA 266: 1535-42.

Komi PV (1984). Biomechanics and neuromuscular performance. Med Sci Sports Exerc 16, 26-28.

Kraemer WJ, Fleck SJ \& Evans WJ (1996). Strength and power training: physiological mechanisms of adaptation. Exerc Sport Sci Rev 24, 363-397.

Kraemer WJ, Patton JF, Gordon SE, Harman EA, Deschenes MR, Reynolds K, Newton RU, Triplett NT \& Dziados JE (1995). Compatibility of high-intensity strength and endurance training on hormonal and skeletal muscle adaptations. J Appl Physiol 78, 976-989.

Krivickas LS, Suh D, Wilkins J, Hughes VA, Roubenoff R \& Frontera WR (2001). Age- and gender-related differences in maximum shortening velocity of skeletal muscle fibers. Am J Phys Med Rehabil 80, 447-455 quiz 456-7.

Lamberts SW, van den Beld AW \& van der Lely AJ (1997). The endocrinology of aging. Science 278, 419-424.

Larsson L, Li X \& Frontera WR (1997). Effects of aging on shortening velocity and myosin isoform composition in single human skeletal muscle cells. Am J Physiol 272, C638C649.

Lauretani F, Russo CR, Bandinelli S, Bartali B, Cavazzini C, Di Iorio A, Corsi AM, Rantanen T, Guralnik JM \& Ferrucci L (2003). Age-associated changes in skeletal muscles and their effect on mobility: an operational diagnosis of sarcopenia. J Appl Physiol 95:1851-60.

Li X \& Larsson L (1996). Maximum shortening velocity and myosin isoforms in single muscle fibers from young and old rats. Am J Physiol 270, C352-C360.

Lindle RS, Metter EJ, Lynch NA, Fleg JL, Fozard JL, Tobin J, Roy TA \& Hurley BF (1997). Age and gender comparisons of muscle strength in 654 women and men aged 20-93 yr. J Appl Physiol 83, 1581-1587. 
Linossier MT, Dormois D, Geyssant A \& Denis C (1997). Performance and fibre characteristics of human skeletal muscle during short sprint training and detraining on a cycle ergometer. Eur J Appl Physiol Occup Physiol 75, 491-498

MacDougall JD, Sale DG, Moroz JR, Elder GC, Sutton JR \& Howald H (1979). Mitochondrial volume density in human skeletal muscle following heavy resistance training. Med Sci Sports 11, 164-166.

McComas AJ, Galea V \& de Bruin H (1993). Motor unit populations in healthy and diseased muscles. Phys Ther 73, 868-877.

McDonagh MJ \& Davies CT (1984). Adaptive response of mammalian skeletal muscle to exercise with high loads. Eur J Appl Physiol Occup Physiol 52, 139-155.

McMurdo ME \& Johnstone R (1995). A randomized controlled trial of a home exercise programme for elderly people with poor mobility. Age Ageing 24: 425-8.

Meuleman JR, Brechue WF, Kubilis PS \& Lowenthal DT (2000). Exercise training in the debilitated aged: strength and functional outcomes. Arch Phys Med Rehabil 81: 312-318.

Ploutz LL, Tesch PA, Biro RL \& Dudley GA (1994). Effect of resistance training on muscle use during exercise. J Appl Physiol 76, 1675-1681.

Sale DG (1988). Neural adaptation to resistance training. Med Sci Sports Exerc 20, S135-S145.

Sale DG (1991). Neural Adaptation to Strength Training. In Strength and Power in Sport, ed. Komi PV, pp. 249-265. Blackwell Science, Oxford.

Snead DB, Birge SJ \& Kohrt WM (1993). Age-related differences in body composition by hydrodensitometry and dual-energy X-ray absorptiometry. J Appl Physiol 74, 770775 .

Staron RS, Karapondo DL, Kraemer WJ, Fry AC, Gordon SE, Falkel JE, Hagerman FC \& Hikida RS (1994). Skeletal muscle adaptations during early phase of heavyresistance training in men and women. J Appl Physiol 76, 1247-1255.

Staron RS, Leonardi MJ, Karapondo DL, Malicky ES, Falkel JE, Hagerman FC \& Hikida RS (1991). Strength and skeletal muscle adaptations in heavy-resistance-trained women after detraining and retraining. J Appl Physiol 70, 631-640.

Staron RS, Malicky ES, Leonardi MJ, Falkel JE, Hagerman FC \& Dudley GA (1990). Muscle hypertrophy and fast fiber type conversions in heavy resistance-trained women. Eur J Appl Physiol Occup Physiol 60, 71-79.

Thompson LV \& Brown M (1999). Age-related changes in contractile properties of single skeletal fibers from the soleus muscle. J Appl Physiol 86, 881-886.

Tinetti ME, Speechley M \& Ginter SF (1988). Risk factors for falls among elderly persons living in the community. N Engl J Med 319: 1701-1707.

Trappe S, Gallagher P, Harber M, Carrithers J, Fluckey J \& Trappe T (2003). Single muscle fibre contractile properties in young and old men and women. J Physiol (Lond) 552, 47-58.

Trappe TA, Lindquist DM \& Carrithers JA (2001). Muscle-specific atrophy of the quadriceps femoris with aging. J Appl Physiol 90, 2070-2074.

Walters TJ, Sweeney HL \& Farrar RP (1990). Aging does not affect contractile properties of type IIb FDL muscle in Fischer 344 rats. Am J Physiol 258, C1031-C1035.

White TP \& Esser KA (1989). Satellite cell and growth factor involvement in skeletal muscle growth. Med Sci Sports Exerc 21, S158-S163. 
Yamauchi J \& Ishii N (2007). Relations between force-velocity characteristics of the knee-hip extension movement and vertical jump performance. Journal of Strength and Conditioning Research 21: 703-709.

Yamauchi J, Mishima C, Fujiwara M, Nakayama S \& Ishii N (2007). Steady-state forcevelocity relation in human multi-joint movement determined with force clamp analysis. J Biomech 40: 1433-42.

Yamauchi J, Mishima C, Nakayama S \& Ishii N (2010). Ageing related differences in maximum force, unloaded velocity and power of human leg multi-joint movement. Gerontology 56: 167-174.

Yamauchi J, Mishima C, Nakayama S \& Ishii N (2009a). Force-velocity, force-power relationships of bilateral and unilateral leg multi-joint movements in young and elderly women. Journal of Biomechanics 42: 2151-2157.

Yamauchi J, Nakayama S \& Ishii N (2008). Blood pressure response to force-velocity properties of the knee-hip extension movement. Eur J Appl Physiol 102: 569-575.

Yamauchi J, Nakayama S \& Ishii N (2009b). Effects of bodyweight-based exercise training on muscle functions of leg multi-joint movement in elderly individuals. Geriatrics \& Gerontology International 9: 262-269. 


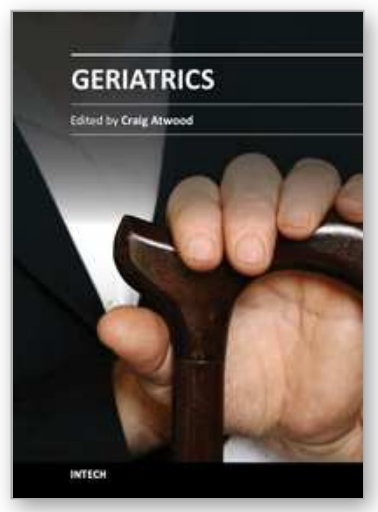

\author{
Geriatrics \\ Edited by Prof. Craig Atwood
}

ISBN 978-953-51-0080-5

Hard cover, 246 pages

Publisher InTech

Published online 24, February, 2012

Published in print edition February, 2012

With the baby boomer generation reaching 65 years of age, attention in the medical field is turning to how best to meet the needs of this rapidly approaching, large population of geriatric individuals. Geriatric healthcare by nature is multi-dimensional, involving medical, educational, social, cultural, religious and economic factors. The chapters in this book illustrate the complex interplay of these factors in the development, management and treatment of geriatric patients, and begin by examining sarcopenia, cognitive decline and dysphagia as important factors involved in frailty syndrome. This is followed by strategies to increase healthspan and lifespan, such as exercise, nutrition and immunization, as well as how physical, psychological and sociocultural changes impact learning in the elderly. The final chapters of the book examine end of life issues for geriatric patients, including effective advocacy by patients and families for responsive care, attitudes toward autonomy and legal instruments, and the cost effectiveness of new health care technologies and services.

\title{
How to reference
}

In order to correctly reference this scholarly work, feel free to copy and paste the following:

Junichiro Yamauchi (2012). Aging and Exercise Training on the Neuromuscular Functions of Human Movements, Geriatrics, Prof. Craig Atwood (Ed.), ISBN: 978-953-51-0080-5, InTech, Available from: http://www.intechopen.com/books/geriatrics/aging-and-exercise-training-on-the-neuromuscular-functions-ofhuman-movements

\section{INTECH}

open science | open minds

\section{InTech Europe}

University Campus STeP Ri

Slavka Krautzeka 83/A

51000 Rijeka, Croatia

Phone: +385 (51) 770447

Fax: +385 (51) 686166

www.intechopen.com

\section{InTech China}

Unit 405, Office Block, Hotel Equatorial Shanghai No.65, Yan An Road (West), Shanghai, 200040, China 中国上海市延安西路65号上海国际贵都大饭店办公楼405单元 Phone: +86-21-62489820

Fax: $+86-21-62489821$ 
(C) 2012 The Author(s). Licensee IntechOpen. This is an open access article distributed under the terms of the Creative Commons Attribution 3.0 License, which permits unrestricted use, distribution, and reproduction in any medium, provided the original work is properly cited. 